\title{
Assembly Elections of India, 2021: Revisiting Assam
}

Dr Pranjit Kumar Sarma ${ }^{+*}$ and Dr Rituparna Bhattacharyya ${ }^{*^{*}}$

\section{Abstract}

In India, Assembly Elections were held in Assam, West Bengal, Kerala, Tamil Nadu and Puducherry in the first half of 2021. Driving this study is an attempt to analyse the election results of the state of Assam where Bharatiya Janata Party (BJP) and its allies, Mitrajot or National Democratic Alliance (NDA), successfully defeated the Indian National Congress (INC), and its allies, Mahajot (Grand Alliance). Drawing primarily upon secondary data and applying GIS techniques, the study makes a critical analogy of how Mitrajot managed to accomplish victory.

Keywords: Assembly Elections 2021; Assam; West Bengal; Kerala; Tamil Nadu; Puducherry; GIS Techniques; India

\footnotetext{
${ }^{+}$Assistant Professor, Department of Geography, Mangaldai College,Mangaldoi, Assam

$¥$ Senior Fellow, Advance HE (formerly Higher Education Academy),UK; Research Consultant and Editor-in-Chief (Joint), Space and Culture, India

*Corresponding Author emails: prangis@gmail.com and rituparna.bhattacharyya@accb.org.uk
} 


\section{Introduction}

Amradahri-topi-lungiwallah manusher sarkar hoiba. Aamrar ma-bhanidder dupatta izzat kora lagbo, amrar mabhanidder burkhar izzat kora lagbo (we beard-cap-lungi wearing people will form the government. The duppata of our mothers and sisters have to be respected. The burqa of our mothers and sisters have to be respected (Kalita, 2021)

These radical-religious-centric statements were made in the third phase of the election rally in Bhabanipur, Bajali district, Assam, on 3 April 2021, by Abdur Rahim, son of Maulana Badruddin Ajmal, the founder and Chief of All India United Democratic Front (AIUDF), on 03 October 2005. ${ }^{1}$ Earlier, at another election rally of 30 March 2021, AIUDF hubris also commented:

Uppar Allah, dharti ka uppar Badruddin Ajmal, Inshallah (there is [a] God above and Ajmal in the ground) (Singh, 2021)

Unsurprisingly, these kinds of seismic statements seeded shockwaves among the common people in a state, who have been fighting against undocumented/ (il)/legal migrants from Bangladesh for decades. This fight culminated in The Assam Movement (or AntiForeigners Agitation), which was launched jointly in 1979 by All Assam Students Union (ASSU) and All Assam Gana Sangram Parishad (AAGSP). This movement ended with the signing of the Assam Accord ${ }^{2}$ on the independence day, that is, on 15 August 1985 between the Union of India, Government of Assam, All Assam Student of Union, and All Assam Gana Sangram Parishad (Barooah Pisharoty, 2019; Bhattacharyya, 2009). During this historical movement, Assam lost 855 martyrs, young Bravehearts and sadly, Khargeswar Talukdar, the first martyr, who lost his life on 10 December 1979 due to police firing hailed from Ujanbarbori village near Bhabanipur, Barpeta district. Weiner (1983) compared this Assam movement with the violence and largescale civil conflicts of Northern Ireland, Malaysia, Cyprus and Lebanon. We argue that this Assamese sub-nationalism movement entrapped in the linguistic and sub-cultural identity (ethnic and indigenous identities) of jati, mati, bheti (nationality, land and the hearth) ${ }^{3}$ (Bhattacharyya, 2019; Dutta, 2017) can be compared to Benedict Anderson's 'creole nationalism'(Anderson, 1983; 2006). Himself an expert on South East Asia's military conflicts, Anderson (2006: 47) commented about creole nationalism:

[W] hether we think of Brazil, the USA, or the former colonies of Spain, language was not an element that differentiated them from their respective imperial

\footnotetext{
${ }^{1}$ The AIUDF was born during the proceedings of the revocation of the Illegal Migrants (Determination by Tribunals) Act, 1983. Popularly known as IMDT Act, it was promolugated in 1983 aimed at detecting and deporting illegal migrants from Bangladesh. However, the nuanced reading of the clauses of the Act appeared that the Act was indeed seving as a barricade to identifying and deporting illegal migrants as the onus of proving that a particular suspected individual accused of being illegal immigrant laid on the informer or the police rather than the suspect. This came to surface following the judgement of the writ petition, Sarbananda Sonowal vs Union Of India on 5 December, 2006 at the Honourable Supreme Court of India (Sinha, nd). The question remains as to what was the need for the IMDT Act, which was specific to Assam alone when in other states, the illegal immigrants can be detected and deportaed under The Foreigners Act, 1946.

${ }^{2}$ Full text of the Assam Accord is available at: The Assam Accord. Government of Assam: Implementation of Assam Accord. https://assamaccord.assam.gov.in/portlets/the-assam-accord

${ }^{3}$ Assam is home to about 30 ethnic groups (Hazarika, 2018) formed from centuries of conglomeration of Austroasiatic, Tibeto-Burman, Indo-Aryan and Tai populations (Saikia, 2004). The physiography of Assam comprises of the mighty Brahmaputra Valley and the Barak (or the Surma Valley) along with Karbi Anglong and North Cachar Hills. The ethnic Assamese is predominantly found in the Brahmaputra Valley, while Bengali people dominate the Barak Valley. The Census of India (2011) reported a dwindle in the percentage of people speaking Assamese, Bodo, Rabha and Santali. In 2001 Census of India, the percentage of Assamese speakers stood at 48.80, which plummeted to 48.38 in 2011 . The percentage of Bengali speaking people increased from 27.54 in 2001 to 28.91 in 2011.
} 
metropoles. All, including the USA, were creole states, formed and led by people who shared a common language and common descent with those against whom they fought.

Anderson's (1983; 2006) 'creole nationalism' can perhaps be connected to the emotional attachments of belonging of a particular community in a particular place, where the community discerns and perceives the danger of losing their identity (Yuval-Davis,2011); here, as already mentioned above, the people of Assam continues to remain petrified by the linguistic and religious threat, primarily because of illegal migration from Bangladesh. However, this study is an attempt to critically discuss the Assembly Elections (Vidhan Sabha) of Assam, 2021. In so doing, it demonstrates how Bharata Janata Party (BJP) and its allies, the Asom Gana Parishad (AGP) and the United People's Party Liberal (UPPL)-the so called Mitrajot or National Democratic Alliance (NDA), as opposed to Mahajot (Grand Alliance) comprising of the Indian National Congress (INC), AIUDF, Bodoland Peoples Front (BPF) and Communist Party of India (Marxist)(CPI (M)) managed to retain its power in Assam for the second consecutive term.

In the first half of 2021, three other statesWest Bengal, Tamil Nadu, Kerala and Puducherry (the Union Territory) went to Assembly polls. As stated above, using GIS techniques, closer scrutiny of the election process of Assam alongside ethnographic observation deriving from the 'insider' status of both the authors, this brief communication is an attempt to analyse the verdict of Assam election critically.
The study begins with a brief overview of the outcome of Assembly Election 2021 of the different states. This is followed by a short discussion of the background to Assam Election 2021. Then we move on to discuss how BJP made an inroad into Assam and successfully held on to power for the second consecutive term.

\section{Assembly Elections of India, 2021}

The fate of the candidates, across the party lines, captured via Electronic Voting Machines (EVM) were declared on 02 May in the aforementioned states. The verdict unveiled that in West Bengal, despite a mighty contest between All India Trinamool Congress, popularly known as TMC and BJP; the TMC, under the leadership of Ms Mamata Banerjee, could win 213 constituencies taking a vote share of $47.9 \%$ while the saffron camp could manage to make in-roads to 77 constituencies with a vote share of $38.13 \%$. In Tamil Nadu, the Dravida Munnetra Kazhagam (DMK) won 133 seats out of 234, embracing a vote share of $37.7 \%$; in Kerala, the incumbent Left Democratic Front (LDF) won 99 constituencies out of 140 , indeed, eight more than the 2016 election. N Rangasamy, the leader of All India N.R. Congress (AINRC), along with BJP as its alliance, won 16 seats out of 30 , making a simple majority. While Figure 1 illustrates the winning parties currently governing the states for the next five years, Table 1 presents the breakdown of the total number of constituencies of the different states. Following this, the party-wise results of the political parties of the respective states are presented in Table 2 .

\begin{tabular}{|l|l|l|}
\hline Table 1: Total Constituencies & in Each State and Union Territory, & Assembly Election, 2021 \\
\hline States/Union Territory & Total Constituencies & Total number of seats to win \\
\hline West Bengal & $294(292$ went to poll) & $\mathbf{1 4 8}$ \\
\hline Tamil Nadu & 234 & $\mathbf{1 1 8}$ \\
\hline Kerala & 140 & $\mathbf{7 1}$ \\
\hline Assam & 126 & $\mathbf{6 4}$ \\
\hline Pudducherry & $\begin{array}{l}\text { 30 plus three nominated } \\
\text { members }\end{array}$ & $\mathbf{1 7}$ \\
\hline
\end{tabular}

Source: Election Commission of India 


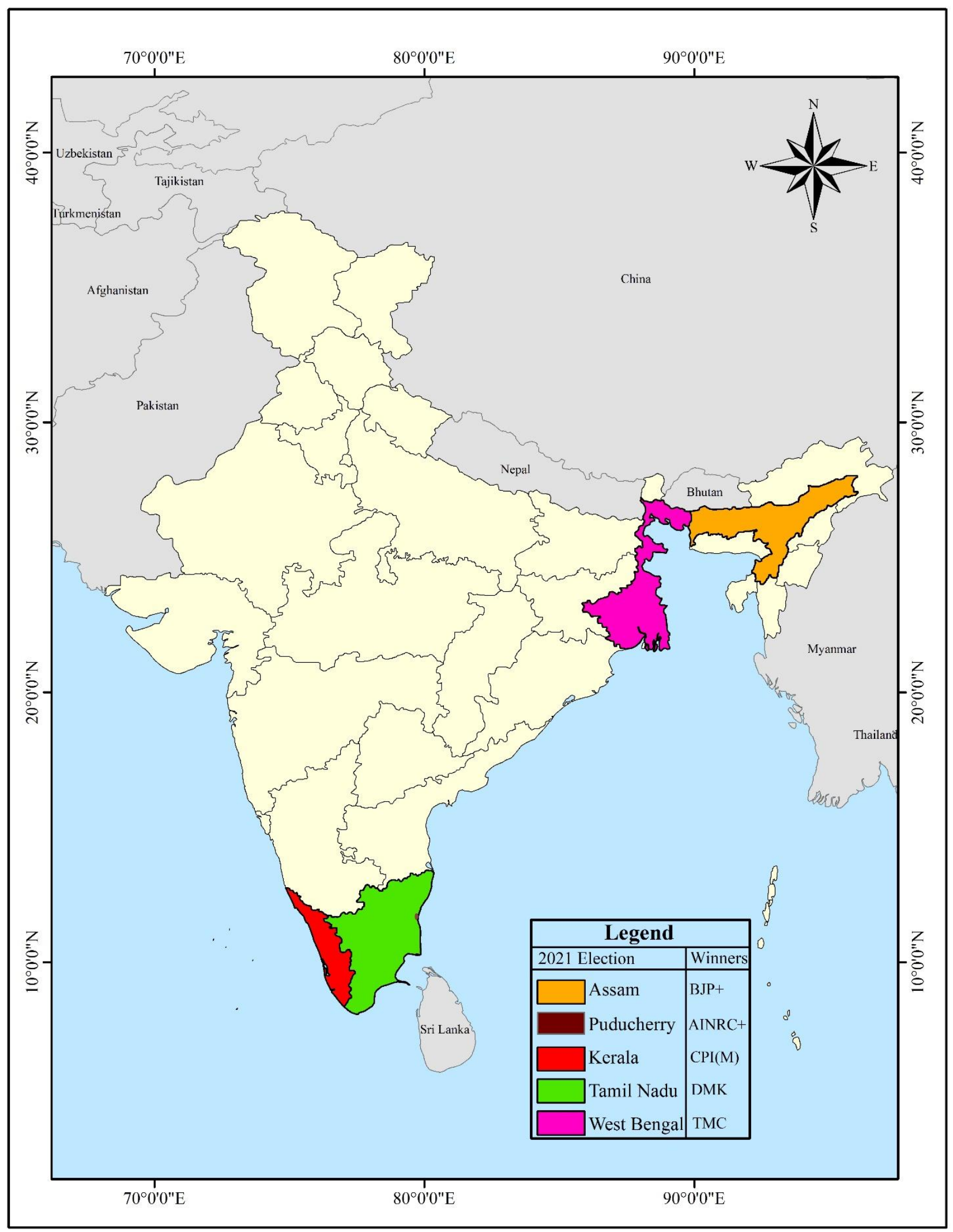

Figure 1: Winners of the Political Parties in the Assembly Elections, 2021 -Assam, West Bengal, Tamil Nadu, Kerala and Puducherry 
Table 2 Party-wise Assembly Election Results, 2021

Political Party

Number of Constituencies Won

Assam

All India United Democratic Front

16

Asom Gana Parishad

9

Bharatiya Janata Party

60

Bodoland Peoples Front

4

Communist Party of India (Marxist)

Independent

Indian National Congress

United People's Party, Liberal

Total

West Bengal

All India Trinamool Congress $\quad 213$

\begin{tabular}{|l|l}
\hline Bharatiya Janata Party & $\mathbf{7 7}$
\end{tabular}

Independent

Rashtriya Secular Majlis Party

1

Total

292

Tamil Nadu

All India Anna Dravida Munnetra Kazhagam $\quad 66$

\begin{tabular}{|l|l}
\hline Bharatiya Janata Party & 4
\end{tabular}

Communist Party of India $\quad 2$

\begin{tabular}{l|l} 
Communist Party of India (Marxist) & $\mathbf{2}$ \\
\hline
\end{tabular}

Dravida Munnetra Kazhagam 133

\begin{tabular}{l|l} 
Indian National Congress & 18
\end{tabular}

\begin{tabular}{l|l}
\hline Pattali Makkal Katchi & 5 \\
\hline
\end{tabular}

\begin{tabular}{|l|l}
\hline Viduthalai Chiruthaigal Katchi & 4 \\
\hline
\end{tabular}

\begin{tabular}{|l|l}
\hline Total & 234
\end{tabular}

Kerala

\begin{tabular}{|l|l}
\hline Communist Party of India & 17
\end{tabular}

\begin{tabular}{|l|l}
\hline Communist Party of India (Marxist) & 62
\end{tabular}

Congress (Secular) 1

\begin{tabular}{|l|l}
\hline Independent & 1 \\
\hline
\end{tabular}

\begin{tabular}{|l|l}
\hline Indian National Congress & 21
\end{tabular}

\begin{tabular}{l|l}
\hline Indian National League & 1
\end{tabular}

\begin{tabular}{l|l} 
Indian Union Muslim League & 15
\end{tabular}

Janadhipathiya Kerala Congress $\quad 1$

Janata Dal (Secular)

Kerala Congress

Kerala Congress (Jacob)

Kerala Congress (M)

Kerala Congress(B)

Loktantrik Janta Dal

National Secular Conference

Nationalist Congress Party

Revolutionary Marxist Party of India

Total

29

26

3

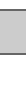

6

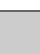

33

8

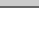

34

Puducherry

\begin{tabular}{|l|l}
\hline All India N.R. Congress & 10
\end{tabular}

\begin{tabular}{l|l}
\hline Bharatiya Janata Party & 6
\end{tabular}

\begin{tabular}{l|l}
\hline Dravida Munnetra Kazhagam & 6
\end{tabular}

\begin{tabular}{l|l}
\hline Independent & 6 \\
\hline
\end{tabular}

\begin{tabular}{|l|l}
\hline Indian National Congress & $\mathbf{2}$
\end{tabular}

$\begin{array}{ll}\text { Total } & \mathbf{3 0}\end{array}$

Source: Election Commission of India. https://results.eci.gov.in/Result2021/partywiseresult-S25.htm?st=S25 


\section{Background to the Election of Assam, 2021}

It remains paramount to mention that even after more than three decades of the signing of the historic Assam Accord but failure to implement Clause 6 of the Assam Accord ${ }^{4}$ (Barooah Pisharoty, 2019), the state of Assam continues to blister under the debates of the National Registrar of Citizens (NRC) ${ }^{5}$ and Citizenship Amendment Act (CAA), 2019. ${ }^{6}$ The CAA has been vehemently criticised by the opposition, leftliberals and common citizens across the spectrum of different states as anti-Muslim (Pulla et al., 2020). In Assam, too, people have demonstrated protests against CAA but with a slightly different twist - not as an anti-Muslim Act but anti-CAA protests were on the grounds of the ongoing controversial debates of NRC; non-execution of the Clause 6 of Assam Accord vis-à-vis protection of the indigenous people of Assam and the persistence of illegal migration of Muslims from Bangladesh. As a result of the misinformation ${ }^{7}$ propounded by some of the leaders and playing on the emotions of the people of Assam, who continue to live in

${ }^{4}$ Clause 6 of the Assam Accord reads: "[c]onstitutional, legislative and administrative safeguards, as may be appropriate, shall be provided to protect, preserve and promote the cultural, social, linguistic identity and heritage of the Assamese people."

${ }^{5}$ As the name implies, NRC is an exercise to incorporate the names of genuine Indian citizens. It was first launched in the state in 1951 stemming from the unrelenting migration from current Bangladesh during the colonial period. Indeed the 1931 Census of India, Assam clearly expressed concern about the growing Muslim population in the state (Census of India 1931, Volume III, Assam, Part I- Report by CS Mullan; see also, Bhattacharyya, 2019). The 1951 NRC included those citizens who were born on or before 26 January 1950, or had been residing in India for at least five years before 26 January 1950, which was the benchmark date. However, with the continued flow of implacable and unabated illegal migration, the honourable Apex Court ordered for a fresh NRC in 2013 taking the cut off date as 24 March 1971, two days before Bangladesh gained independence from Pakistan (Das et al., 2020). In the NRC review process, 65 million documents and 32.9 million people were scrutinised bearing an expense $\$ 178$ million of taxpayers money. The NRC process revealed $40,70,707$ people as illegal residents of the state. The list however appeared to be flawed. The final revised list of the NRC was published 31 August 2019, which excluded nearly 2 million people, constituting approximately $6 \%$ of the population of Assam as trepidation of facing a cultural and linguistic threat from the Bengali people from Bangladesh; it was saddening to witness that anti-CAA protests turned out to be violent (Deka, 2019; Hasnat, 2020; Pandey, 2019). Five persons succumbed to firing by security forces; approximately 175 were arrested, and about 1400 were detained (Deka, 2019; Hasnat, 2020; Pandey, 2019). Evidently, some leaders used anti-CAA protests to climb the political ladder. For instance, with the support of AIUDF and Congress, Mr Ajit Bhuyan became a member of Rajya Sabha (the upper house of Parliament) and floated the political party Anchalik Gana Morcha (AGM) (Regional People's Front) in June 2020. They contested as a part of the Mahajot. Advocate Arup Borbora launched the United Regional Party, Assam (ARPA) party on 20 August 2020. Mr Jahnu Barua, the noted filmmaker, is a quasi-static guiding force behind the United Regional Party-Assam (Hasnat, 2020), and actor Jerifa Wahid rendered support to ARPA. ${ }^{8}$ Seemingly, with the symbol of Ship driving in water, the Assam Jaitya Parishad (AJP) was

'stateless'. Of these 2 million, many are indigenous population of Assam and the Hindu refugees who fled Bangladesh Liberation War of 1971 (Das et al., 2020), who had failed to furnish appropriate documents. This final (draft) of the NRC list, which escalated controversy remains sub judiced in the honourable Apex Court following the move by the state government praying for $20 \%$ sample reverification of names already incorporated in the draft NRC in those districts bordering Bangladesh and a $10 \%$ sample reverification of names in the rest of the districts (Singh, 2021a).

${ }^{6}$ The Citizenship Amendment Act, 2019 (CAA), was passed by the Indian Parliament on 11 December 2019 and made into an Act on 12 Decemnber 2019 with the assent of the Honourable President of India. This Act, which is an amendment of the Citizenship Act, 1955 aims at providing citizenship to those religious minorities especially the Hindus, Christians, Sikhs, Buddhists and Parsi communities who arrived in India as refugees on or before 31 December 2014 escaping religious persecution from Pakistan, Bangladesh and Afghanistan (The Citizenship Amendment Act, 2019; Pulla et al., 2020).

${ }^{7}$ That Hindus from Bangladesh will arrive and settle in Assam

${ }^{8}$ New regional political party ARPA formed by noted lawyer Arup Borbora (2020, 27 August). The Sentinel. https://www.sentinelassam.com/topheadlines/newregional-political-party-arpa-formed-by-noted-lawyerarup-borbora-497623 
founded under the leadership of the former AASU leader, Lurinjyoti Gogoi, and another student organisation called Asom Jatiyatabadi Yuva Chhatra Parishad in September 2020. Eighty-one candidates contested from AJP for 82 Constituencies, but none could win, including Lurin Jyoti Gogoi, who had contested from the Duliajan and Naharkatia constituencies. In a similar way, the renowned activist Mr Akhil Gogoi and the founder of Krishak Mukti Sangram Samiti (KMSS), with the support of 70 alliances, formed Raijor Dol, fielding 19 candidates. However, the activism of Akhil Gogoi and himself being a popular public figure for over one and a half-decade had minimal impact on the election results. Out of the 19 seats, only Akhil Gogoi managed to win from the Sibsagar constituency. Arguably, despite the question of Assamese subnationalism, anti-CAA protests vis-à-vis the formation of solid regionalism on which these parties were formed to take on BJP-led government failed to display its robust footprint; the BJP and its allies could very well understand it (Hasnat, 2020). In Hasnat's (2020) interview, Pulak Gohain, Assam BJP Vice President, remarked:

People of Assam have realised why some had led protests against CAA. Because they had political interests - after forming new parties, they now want to win elections. How many Bangladeshis have come after one year of protests? Of course, the Assamese community shares sentiments, but the issue cannot be manipulated for political gains. People will vote for development and for their future, not for insecurities (Hasnat, 2020).

Now the question remains, did the people of Assam vote for development? Indeed 'yes'. The following section probes this question.

\section{Politics of Development}

To examine the narrative of 'politics of development', it is vital to reflect, step back and re-look at the history of governance of Assam. It is interesting to note that Assam, despite being a solid hub of ethnic and indigenous people, remained a Congress governed bastion since
India's independence in 1947 except for 1978 when Janata Party ruled for five years (19781983), in addition to 1985 and 1996 led by AGP. In fact, AGP is the only regional party that won for the first time in Assam in 1985 following the signing of the Assam Accord, piggybacking the issue of illegal migration from Bangladesh (Barooah Pisharoty, 2019; Bhattacharyya, 2009). From 2001 again till 2011, the state of Assam had a Congress-led government. The first and the second parties in Assam polls and the percentage of the vote share of the first and the second political parties since 1951 is presented in Figures 2 and 3. Since 2016, the BJP made inroads to Assam, riding on the vehicle of election results - out of 126 seats, BJP and its 2016 allies \{AGP and Bodoland People's Front (BPF)\} won respectively 60, 14 and 12 seats making a total of 86 (Dutta, 2017). The Congress could retain 26 seats; AIUDF managed to win 13, while others won one seat. In the 2019 Lok Sabha (House of the people or Lower House), the BJP won nine out of 14 Lok Sabha seats in the state. Earlier in the 2014 Lok Sabha election, BJP won seven Lok Sabha constituencies. Dr Himanta Biswa Sarma, the new Chief Minister of Assam, who had joined BJP on 23 August 2015, was the prime architect behind BJP's entry to Assam. Dr Sarma, however, began his political career as a Congress man who won the Assembly election for the first time in 2001, defeating the AGP stalwart late Mr Brigu Kumar Phukan from the Jalukbari Constituency. Assam has started witnessing 'politics of development' and 'hope' since Dr Sarma was bestowed responsibility in the Congress Ministry led by the late former Chief Minister Tarun Gogoi. Dr Sarma operated important portfolios (both state and cabinet) in health and education from 2002 to 2014. His prudence, hard work and diligence spelt out through his works made him emerge as a powerful Minister in the Gogoi cabinet. For instance, under Dr Sarma's leadership, three medical colleges were built in Jorhat, Barpeta and Tezpur, and five more medical colleges in Diphu, Nagaon, Dhubri, North Lakhimpur and Kokrajhar are in the various stages of construction. As an Education Minister, Dr Sarma introduced the Teachers Eligibility Test (TET) by 
eliminating the interview process and appointed 50,000 teachers. Similarly, other government jobs, such as recruitments at the National Rural Health Mission (NRHM) were done in absolute transparency. There are many other examples of his works through which Assam, ${ }^{9}$ a developing state of India, started seeing 'lights of development'. Indeed, these steps towards positive development made $\mathrm{Dr}$ Sarma a 'blueeyed boy' of Mr Gogoi and became a star campaigner of the Congress party for the 2006 and 2011 Assembly Elections. Post-2011, Dr Sarma developed some form of a rift with the Congress Party and tendered his resignation on 21 July $2014 .{ }^{10}$ The following section discusses the Assembly Elections 2021.

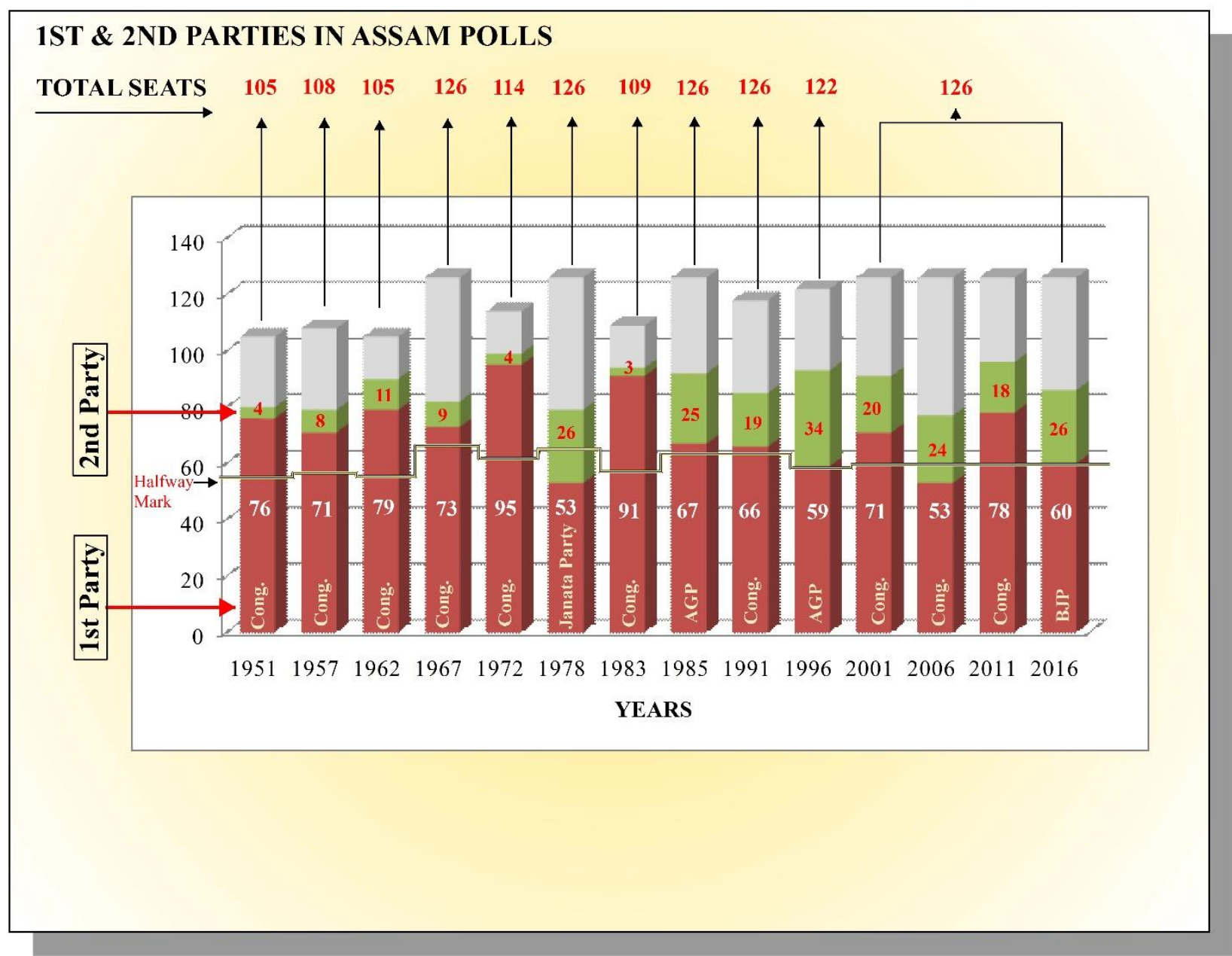

Figure 2

Source: Election Commission of India

\footnotetext{
${ }^{9}$ According to the Assam Budget Analysis, 2021, the GDP of Assam stands at INR 4.09 trillion (or US\$57 billion) (Highlights of Budget, 2020-2021).

10 It is not to say that only Dr Sarma quit Congress Party; many other stalwarts from different states; to name a few, Jyotiraditya Madhavrao Scindia (Madhya Pradesh); Rita Bahuguna Joshi, Jitin Prasada (Uttar Pradesh) followed
}

Dr Sarma. But one has to acknowldge that Dr Sarma was built a political leader by the Congress Party albeit he learned everyday politics since the age of 9 when he started actively taking part in the Assam Movement (19791985) with the leaders, Mr Prafulla Kumar Mahanta and late Mr Brigu Kumar Phukan and then as a student leader at Cotton College (now Cotton University). 
Figure 3: 1st and 2nd Party Vote Share in Assam, 1951-2016

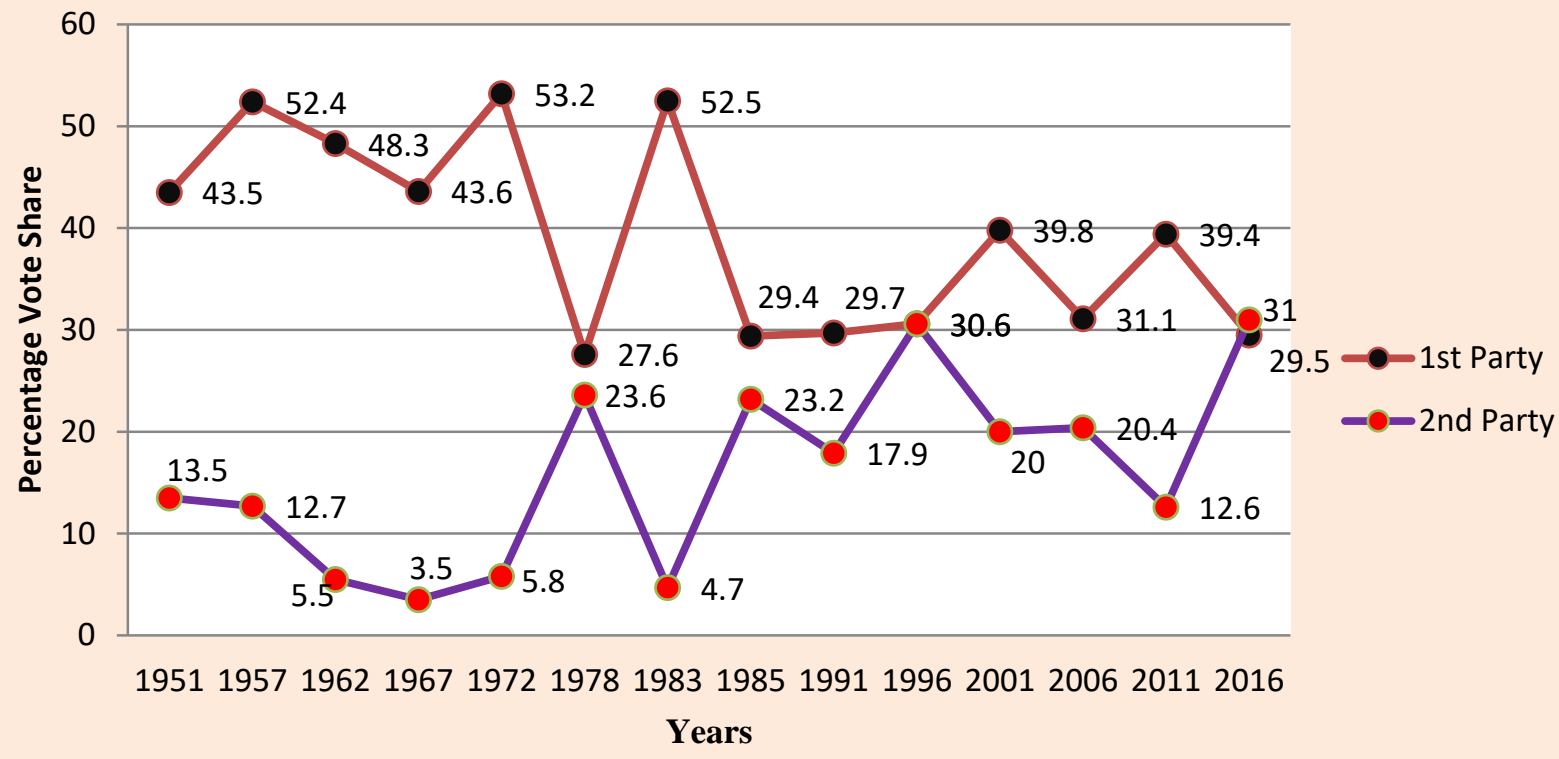

Source: Election Commission of India

\section{Assam Assembly Elections 2021}

Perhaps, the BJP could realise that Dr Sarma carries the values of a warrior - a man with a rush of energy who always works for a broader picture, thinks like a 'soldier' rather than a 'ruler'. On the eve of 2021 Assembly Elections, Dr Sarma corraled with the allies, AGP and United People's Party, Liberal (UPPL), divorcing its former partner, BPF of Bodoland Territorial Area Districts (BTAD). Dr Sarma understands the pulse of the people, so while strategising candidates for the constituencies, he applied the subtle and pedantic forms of thinking, considering the 'attention to details' of every local component of each of the 126 constituencies. It is important to reflect on the 2019 General Election where ugly forms of 'memes' and 'jibes' were hurled against honourable Prime Minister, Mr Narendra Damodar Modi, calling him Chowkidar Chor Hai (the gatekeeper is a thief). Following the 'unpleasant negativities' against a sitting Prime Minister, the BJP leaders and workers and the allies too drove it in a 'positive way' by changing their social media handles into Main Bhi Chowkidar (I am also a gatekeeper). In a way, the 'jibes' helped the NDA accomplish their goals in the form of an election mandate. In the Assam election, too, similar strategies were adopted. The youths developed a 'meme' Mama meaning 'uncle' referring to Dr Sarma. Dr Sarma capitalised on this 'meme' addressing in the election rallies Mama-Bhagin (unclenephew/niece) relationship helping Mitrajot win 75 seats as opposed to 51 by Mahajot. The difference in vote share between Mitrajot and Mahajot, however, is meagre $\{(33.21+7.84+3.39)-(29.66+9.29+3.39+0.45)\}$ and stands at 1.65 per cent (Figure 5), indicating a strong opposition. There were a total of $2,33,74,087$ general electors in the state, of which 1,91,76,847 exercised their franchise. Interestingly, 0.219 million or 1.14 per cent of voters pressed the NOTA (None of the Above) option, markedly demonstrating their dissatisfaction with the parties' right candidate. This is perhaps a lesson to be learned by all parties. The details of the election results are displayed in Figure 4, and the vote share of the respective parties is shown in Figure 5. Appendix I presents the details of votes gained by the candidates across the parties in all the 126 constituencies. 


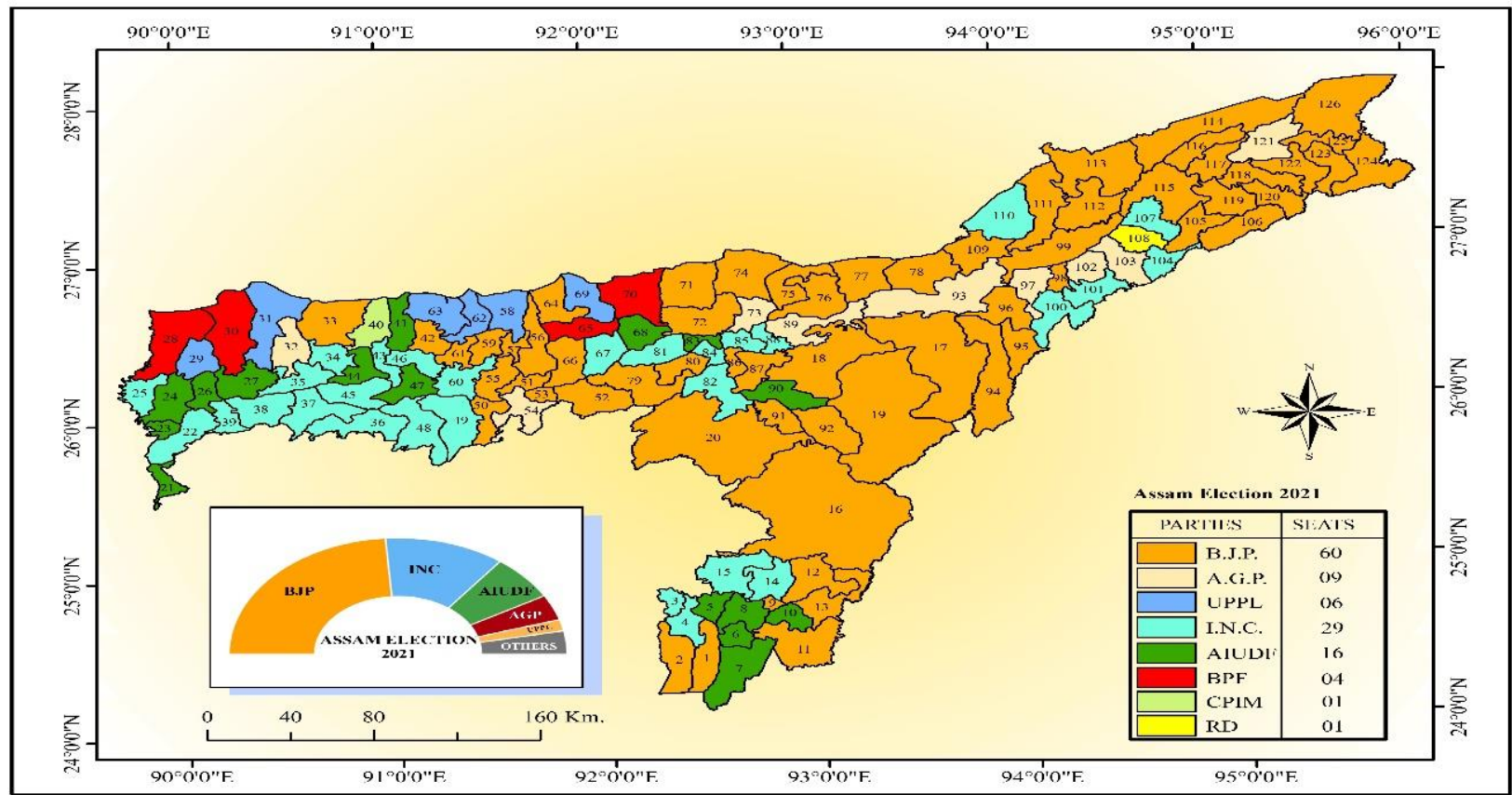

Figure 4: Results of Assam Election 2021

Source: Election Commission of India

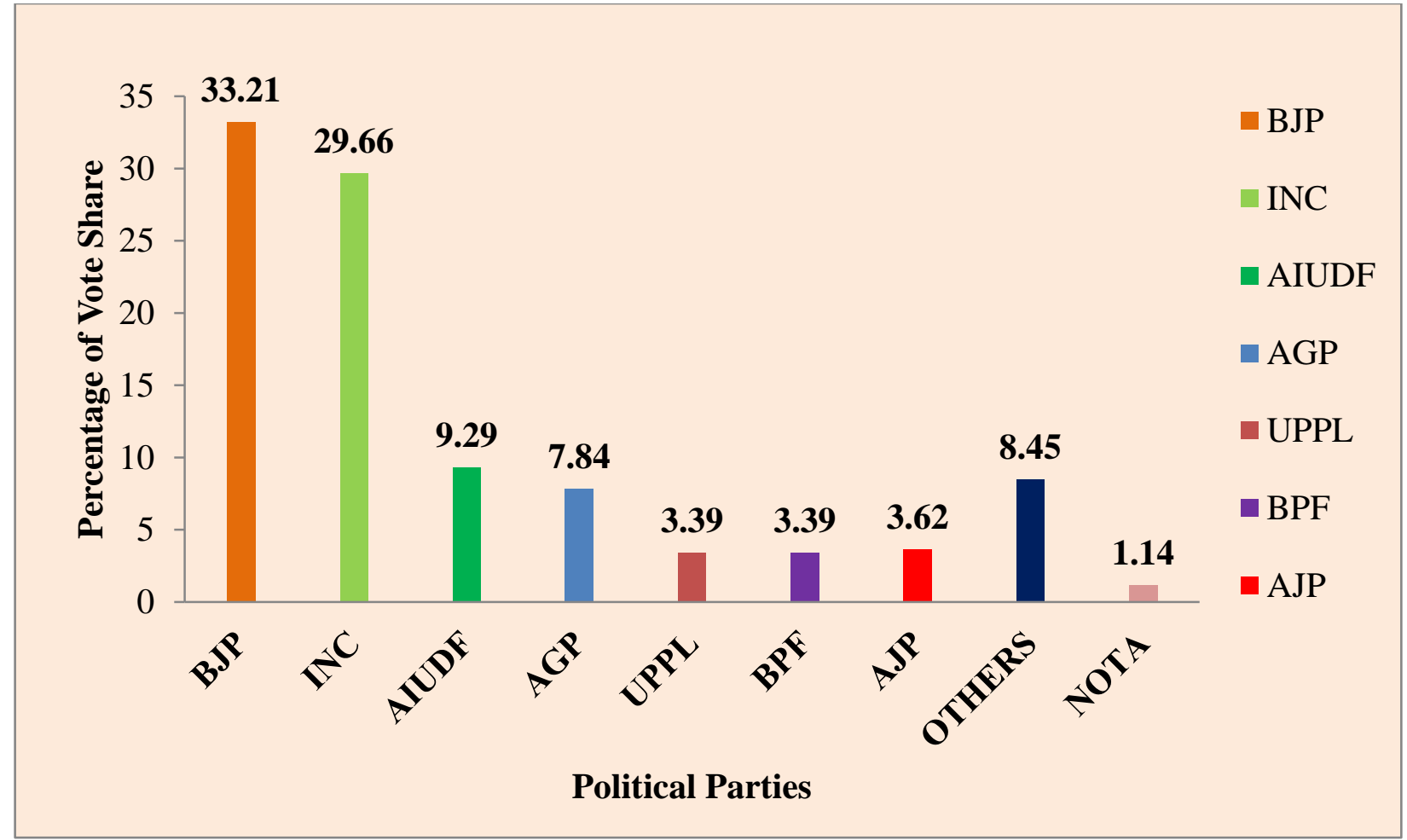

Figure 5: Percentage of Vote Share of the Political Parties

Source: Election Commission of India

In his article titled How BJP retained Assam, Dutta (2021) made the following observation:

The BJP has achieved this victory through multiple strategies. It manufactured social perceptions, implemented competitive populist schemes and brought almost all mainstream tribal ethnic outfits into its fold. During the first wave of the pandemic, the BJP regained the political legitimacy it had lost during the period of the CAA enactment through initiatives such as the Arogya Nidhi. By exempting the three Sixth Schedule council areas - the Bodo Territorial 
Council (BTC), the Karbi Autonomous Council and the Dima Hasao from the purview of the CAA - the BJP government succeeded in luring away many ethnic nationalist organisations from the anti-CAA movement. While the two new regional political parties - the Asom Jatiya Parishad (AJP) and the Raijor Dal (RD) - centred on the anti-CAA sentiments, the BJP limited the anti-CAA fervour to a section of the Assamese speaking non-tribal population. The victory of Akhil Gogoi, president of the $\mathrm{RD}$, is more a reflection of the peoples' wrath against his extended imprisonment. Meanwhile, the grand alliance forged by the Congress with the AIUDF, the Left, the BPF and a few other smaller regional parties failed to mitigate inner and intra fighting among the parties and produce a common minimum programme.

The BJP consolidated its base by foregrounding developmentalism, accompanied by hyper populism. The decades-long work by the RSS had turned the tea tribes, particularly in upper Assam, to BJP supporters. The community received the highest patronage from the incumbent government. The number of beneficiaries under various schemes such as the "Orunodai" under the National Food Security Act also increased substantially. It also launched new and innovative schemes for different segments of society. Not a single segment of society remained untouched by the populist beneficiary schemes, including girls and women belonging to the minority Muslim community. The BJP's Sangkalpa Patra 2021 is a case in point. The BJP also successfully engineered the perception that Narendra Modi stands for all-inclusive development (Dutta, 2021).

While we endorse the majority of the views of Dutta (2021) and have already argued above that the parties founded on anti-CAA sentiments had failed to hold much water, Dutta (2021) appears to have incongruous views. He talks about the BJP governnment's populist schemes, the efforts of the government to bring the tribes together and work towards 'inclusive development' on one hand and hyper populism on the other hand. Arguably, populist schemes are necessary for a state where 31.98 per cent of the populations still live below the poverty line (Niti Aayog, 2020), signalling that they are extremely poor. As insiders of the state, we have observed that the quality of life of even those living above the poverty line (APL) are multi-dimensionally poor. It is the responsibility of any government to have welfare schemes for its citizens. Of course, these should be flagship schemes for the support of its citizens as and when in need.

Regarding hyper populism, we question whether leaders do not have to connect with the common people? Over the years, Dr Sarma and his BJP comrades have demonstrated that they are indeed peoples' men by connecting with the grassroots people. This connection was further reinforced by the first phase of the Covid 19 pandemic when Assam was projected as an exemplary state in tackling the virus. And the proactive leadership demonstrated by Dr Sarma and his team has been labelled as 'workaholic'. Hence, the trenchancy about 'hyper populism' and 'populist schemes' disparages and insults the common people. Every citizen should have a fundamental right to live in dignity. We argue that if the poor do not have to think about their daily bread, they can perhaps be far more creative and imaginative. And the BJP in Assam has been able to add "swaabhimaan (selfrespect) to their tenacity and elevate their hopes" (Pulla, 2017: 1). Pulla (2017), however, made this argument in the context of the Prime Minister, Mr Modi. For this, Pulla (2017) applied Gramscian 'counter hegemony' to describe $\mathrm{Mr}$ Modi as an 'organic intellectual'(Gramsci, 1987: 161-323), a thinking being, who himself hails from a humble background and has emerged as a messiah (saviour) of the poor (Pulla, 2017). Similarly, the BJP group of workers under $\mathrm{Dr}$ Sarma has been demonstrating 'counter hegemonic' leadership in the state of Assam. 
In one of the articles published in The Hindu, the scholars argue that 'Hindu consolidation pays off for BJP' (Palshikar et al., 2021). Is it really so? According to Census (2011), the Hindus constituted 61.47 per cent, and the Muslims comprised 34.23 per cent of the demography of Assam. In 2021, it is estimated that the percentage of the Muslim population has increased to over 40 per cent, consisting of about 14.02 million of the total population of Assam. The decadal increase of the Muslim population is more than 31.3 per cent, and 11 districts out of 34 are Muslim majority districts in Assam. This means that the Hindu population has decreased to less than 60 per cent, which is indeed a very worrying trend. Some of the districts demonstrating proliferation in the Muslim population are Baksha (14.29 per cent), Barpeta (74.94 per cent), Bongaigaon (50.22 per cent), Cachar (37.71 per cent), Chirang (22.66 per cent), Darrang (64.34 per cent), Dhubri (73.49 per cent), Goalpara (57.52 per cent), Hailakandi (60.31 per cent), Hojai (53.64 per cent), Kamrup (39.66 per cent), Kamrup Metropolitan (12.05 per cent), Karimganj (56.36 per cent), Kokrajhar (28.44 per cent), Morigaon (52.56 per cent), Nagaon (56.20 per cent), Nalbari (35.96 per cent), Sonitpur (22.74 per cent), South Salmara Mankachar (95.19 per cent), Udalguri (12.66 per cent). Because of the rising trend of the Muslim population, the leaders of Mahajot perhaps rode on their preconceived opinion that the mandate would favour them. And that is why people of Assam could witness a colossal horse-trading melodrama by the leaders and the contestants of Mahajot. However, despite the increasing trend of the Muslim population, it can be deduced from Figure 5 that the people of Assam are smart and intelligent enough to vote according to the choice of their 'candidates' regardless of religion. We argue that 'polarisation' is a media portrayal term rather than reality. However, it does not mean that the question of Assamese sub-nationalism (linguistic and cultural identity) (Bhattacharyya, 2019; Dutta, 2017) hinged on 'creole nationalism' (Anderson, 1983; 2006) has become blurred. It is rather an emotive issue and continues to remain active in the minds and hearts of the people of Assam. However, it is arguable that peoples' election mandate has been for 'leadership of development and hope' rather than political ideology. We, however, urge that further indepth research is necessary to counter our arguments.

\section{Conclusion}

This study has critically reviewed the results of the Assam Assembly election 2021. People's mandate has been for good governance and development apace with high hopes to see a developed Assam in the next five years under the 'double engine sarkar' (double engine government-both in the central government and state government governed by the same ruling party) (Palshikar et al., 2021). Of course, the government has many challenges - to name a few-Covid 19, floods and erosion, illegal migration, the war against drugs, corruption, syndicates and many more. One has to acknowledge that since 2016, the BJP government, under the leadership of $\mathrm{Mr}$ Sarbananda Sonowal, did work for reduced corruption, crime and rhino poaching. The time will speak how the double engine sarkar manages to tackle the state's challenges that lie ahead.

\section{References}

Anderson, B. (2006). Imagined communities. Verso.

Anderson, B. (1983). Imagined communities:

Reflections on the origin and spread of nationalism. Verso.

Barooah Pisharoty, Sangeeta (2019). Assam, The Accord, the Discord. Penguin Random House

Bhattacharyya, Rituparna (2019). Chapter Six: Did India's Partition lead to Segregation of North East India? In A. Ranjan. (ed). Partition of India: Postcolonial Legacies. Routledge, 105-131

Bhattacharyya, Rituparna (2009). Examining the Changing Status and Role of Middle-Class Assamese women: Lessons from the Lives of University Students, PhD thesis. Newcastle University, UK 
Census of India (1931). Vol. III: Assam. Part I: Report.

https://dspace.gipe.ac.in/xmlui/handle/10973/ 37319

Census of India (2011). Paper 1 of

2018. Language: India, States and Union

Territories (Table C-16). Office of the Registrar General, India.

https://www.censusindia.gov.in/2011Census/C16_25062018_NEW.pdf

Census (2011). Assam Religion Census 2011. https://www.census2011.co.in/data/religion/st ate/18-assam.html

Das, Tulshi Kumar, Bhattacharyya, Rituparna, \& Sarma, Pranjit (2020). Revisiting geographies of nationalism and national identity in Bangladesh. Geojournal, 10.1007/s10708-020-10305-1

Deka, Kaushik (2019, 12 December). Citizenship Amendment Bill protests: Here's why Assam is burning. India Today.

https://tinyurl.com/2jhxxz25

Dutta, Akhil Ranjan (2021, 03 May). How BJP retained Assam. The Indian Express.

https://indianexpress.com/article/opinion/colu mns/assam-bjp-win-assembly-election-results7299593/

Dutta, Akhil Ranjan (2017). BJP's Electoral Victory in Assam, 2016: Co-opting the Khilonjiyas. Social Change, 47 (1), 108-124, DOI: $10.1177 / 0049085716683114$

General Election to Vidhan Sabha Trends \& Result May-2021. Election Commission of India. https://results.eci.gov.in/Result2021/partywise result-S03.htm

Gramsci, Antonio (1987). Selections from Prison Notebooks. International

Hazarika, Sanjoy. Who is an Assamese?Business Line: The Hindu. https://tinyurl.com/24zz87bu

Hasnat, Karishma (2020, 12 December). A year after Assam anti-CAA stir, families of those killed lend support to renewed movement. The Print. https://tinyurl.com/emu26m63

Highlights of Budget, 2020-2021, Assam Budget, Government of Assam. http://assamassembly.gov.in/budget-highlights2020-21.pdf

Kalita, Prabin (2021, 3 April). Ajmal son's 'dadhi, topi \& lungi' salvo sends shockwaves. The Times of India. https://tinyurl.com/wank8kvt

NITI Aayog (2020).

https://sdgindiaindex.niti.gov.in/\#/ranking

Palshikar, Suhas; Rana, Manjesh, Sharma, Dhruba Pratim and Tripathi Vikas (2021, 07 May). Assam Assembly Elections | Hindu consolidation pays off for BJP. The Hindu. https://tinyurl.com/2v79fcy3

Pandey, Munish Chandra (2019,16 December). Assam CAA protest: 4 dead in police firing, 175 arrested, more than 1400 detained. India Today. https://tinyurl.com/kyfevnz8

Pulla, Venkat, Carter, Elizabeth, and Bhattacharyya, Rituparna (2020). Recognising, Understanding and Responding to Racism in India. In Pulla, Venkat Rao., Bhattacharyya Rituparna, \& Bhatt Sanjai (eds). Discrimination, Challenge and Response: People of North East India. Palgrave Macmillan, DOI: 10.1007/978-3030-46251-2_10, 177-195

Pulla, V. R. (2017). Gramscian 'Counter hegemony' in Narendra Modi's New India Perspective. Space and Culture, India, 4(3), 1-6. https://doi.org/10.20896/saci.v4i3.247

Saikia, Yasmin (2004). Fragmented Memories: Struggling to be Tai-Ahom in India. Duke University Press

Singh, Bikash (2021, 30 March). There is God above and Ajmal in the ground: AIUDF chief Badruddin Ajmal. The Economic Times. https://tinyurl.com/k2zcxwrv

Singh, Bikash (2021a, 31 May). Can't issue rejection slips without Supreme Court order: NRC official. The Economic Times. https://tinyurl.com/tbzkr8ss

Sinha, S. (nd). Supreme Court of India:

Sarbananda Sonowal vs Union Of India on 5 December 2006.

https://indiankanoon.org/doc/1436100/

The Citizenship Amendment Act, 2019. No47 of 2019. Ministry of Law and Justice. The Gazette 
of India.

https://egazette.nic.in/WriteReadData/2019/21 4646.pdf

Yuval-Davis (2011). Belonging and the politics of belonging. In J. McLaughlin, P. Phillimore, \& D. Richardson (eds.). Contesting recognition: Culture, identity and citizenship. Palgrave Macmillan, 20-35

Weiner, M. (1983). The Political Demography of Assam's Anti-Immigrant Movement. Population and Development Review, 9(2), 279-292

\section{Conflict of Interest}

This is a solicited study funded by Alliance for Community Capacity Building in North East India, a UK registered charity (registered no. 1106666) of Charity Commission for England and Wales in association with Prag Foundation for Capacity Building, Guwahati 781019, a public charitable trust registered under the Indian Trust Act, 1882. We declare that this study has not been submitted elsewhere or not considered for publication in another outlet. We have no other conflict of interest to declare.

\section{Acknowledgements}

We offer our indebtedness on record to Dr Vikas Tripathi, Assistant Professor, Department of Political Science, Gauhati University and $\mathrm{Mr}$ Debasish Baruah, Journalist, Kaziranga (Kohora), Assam for meticulously going through the manuscript and suggesting the required changes which have brought qualitative improvement in the article.

\section{Author Contribution Statement}

After we received the invitation requesting us to contribute a study on Assam Assembly Election 2021, both of us met over what's app video call and conceived the idea and the way to go forward with the analysis. While the first author contributed the GIS works, prepared majority of the tables and figures, the second author finalised the draft. The final draft was reviewed and edited by both authors. 


\section{ASSAM ASSEMBLY ELECTION, 2021}

\begin{tabular}{|c|c|c|c|c|c|c|c|c|c|c|c|c|c|c|c|}
\hline PARTY / CONSTITUENCY & 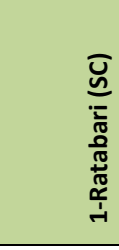 & 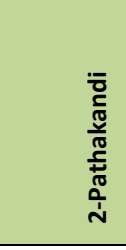 & 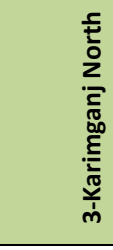 & 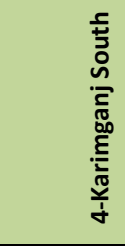 & 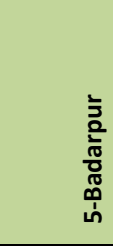 & 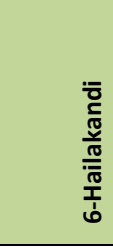 & 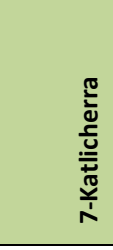 & 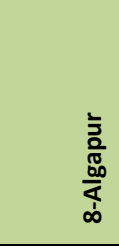 & 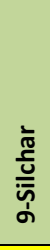 & 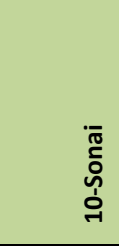 & 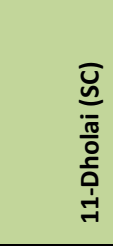 & 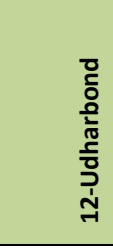 & 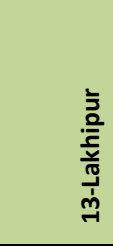 & 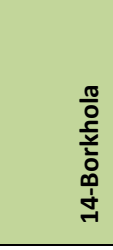 & 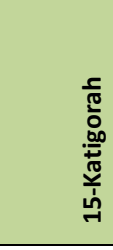 \\
\hline TOTAL VOTER & 173974 & 190434 & 199602 & 192139 & 162441 & 163505 & 180247 & 163206 & & 184450 & 191374 & 163771 & 166933 & 152761 & 189031 \\
\hline BJP & 84711 & 74846 & 52674 & $\mathbf{x x x}$ & 50504 & 47303 & 66798 & 49181 & & 52283 & 82568 & 61745 & 55341 & 57402 & 76329 \\
\hline INC & 48490 & 70379 & 60998 & 88909 & $x x x$ & $x x x$ & 2931 & $x x x$ & & $x x x$ & 62176 & 59060 & 42641 & 64433 & 83268 \\
\hline AGP & $x x x$ & 543 & $\mathbf{x x x}$ & 56422 & $x x x$ & $x x x$ & $x x x$ & 7549 & & $x x x$ & $x x x$ & $x x x$ & $x x x$ & $x x x$ & $x x x$ \\
\hline AIUDF & $x x x$ & $x x x$ & $\mathbf{x x x}$ & $x x x$ & 74452 & 71057 & 79769 & 66785 & & 71937 & $x x x$ & $x x x$ & $x x x$ & $x x x$ & $x x x$ \\
\hline AJP & $x x x$ & $x x x$ & $\mathbf{x x x}$ & $x x x$ & 2123 & $x x x$ & $\mathbf{x x x}$ & $\mathbf{x x x}$ & & $x x x$ & 381 & 811 & 2991 & 776 & $x x x$ \\
\hline BPF & $x x x$ & $x x x$ & $\mathbf{x x x}$ & $x x x$ & $x x x$ & $x x x$ & $\mathbf{x x x}$ & $\mathbf{x x x}$ & & $x x x$ & $x x x$ & $x x x$ & $x x x$ & $x x x$ & $x x x$ \\
\hline UPPL & $x x x$ & $x x x$ & $\mathbf{x x x}$ & $x x x$ & $x x x$ & $x x x$ & $\mathbf{x x x}$ & $\mathbf{x x x}$ & & $x x x$ & $x x x$ & $x x x$ & $x x x$ & $x x x$ & $x x x$ \\
\hline CPI(M) & $x x x$ & $x x x$ & $\mathbf{x x x}$ & $x x x$ & $x x x$ & $x x x$ & $\mathbf{x x x}$ & $\mathbf{x x x}$ & & $x x x$ & $x x x$ & $x x x$ & $x x x$ & $x x x$ & $x x x$ \\
\hline NOTA & 1200 & 1288 & 1180 & 985 & 1706 & 1063 & 745 & 442 & & 1231 & 1561 & 1494 & 1536 & 1105 & 1112 \\
\hline OTHERS & 2410 & 3651 & 31893 & 3964 & 2707 & 9413 & 3648 & 11069 & & 21883 & 3365 & 7331 & 21537 & 738 & 1868 \\
\hline RAIJOR DAL & $x x x$ & $x x x$ & $x x x$ & $x x x$ & $x x x$ & $x x x$ & $x x x$ & $x x x$ & & $x x x$ & $x x x$ & $x x x$ & $x x x$ & $x x x$ & $x x x$ \\
\hline REJECTED & 364 & 498 & 421 & 387 & 319 & 195 & 187 & 145 & & 319 & 214 & 285 & 273 & 346 & 31 \\
\hline TENDER & $x x x$ & $x x x$ & $x x x$ & $x x x$ & $x x x$ & $x x x$ & $x x x$ & $\mathrm{xxx}$ & & $\mathrm{xxx}$ & $x x x$ & $x x x$ & $x x x$ & $x x x$ & $x x x$ \\
\hline TOTAL VOTE CAST & 137175 & 151205 & 147166 & 150667 & 131811 & 129031 & 154078 & 135171 & & 147653 & 150265 & 130726 & 124319 & 124800 & 162608 \\
\hline
\end{tabular}




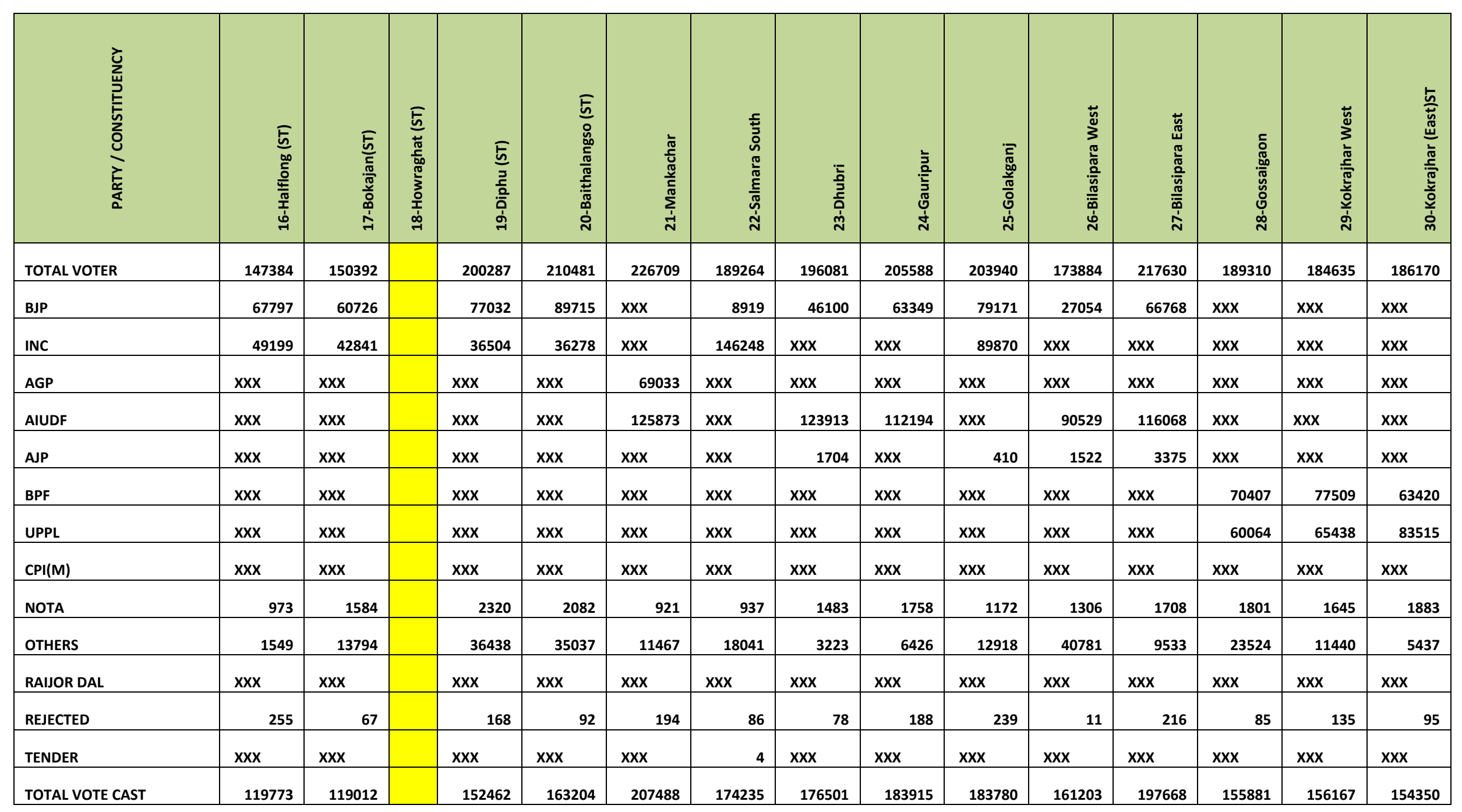




\begin{tabular}{|c|c|c|c|c|c|c|c|c|c|c|c|c|c|c|c|}
\hline 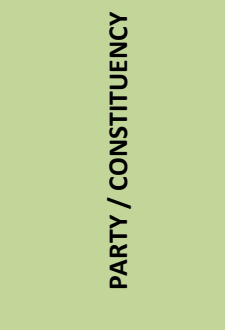 & $\begin{array}{l}\overline{\bar{z}} \\
\bar{n} \\
\dot{m}\end{array}$ & 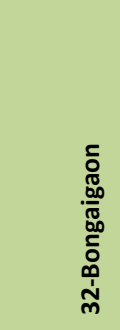 & 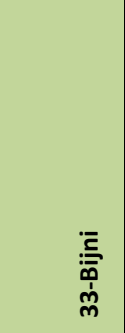 & 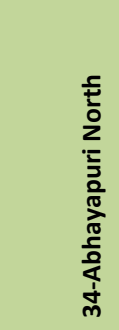 & 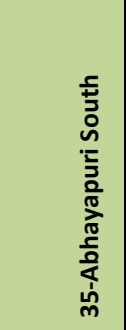 & 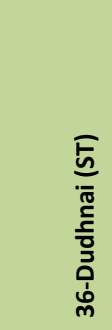 & 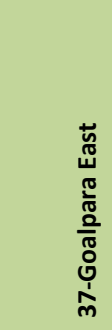 & 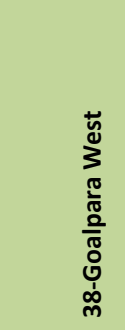 & 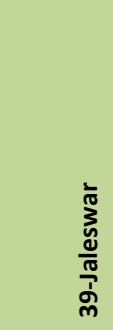 & 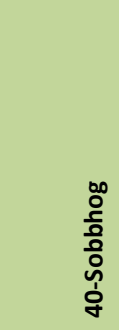 & 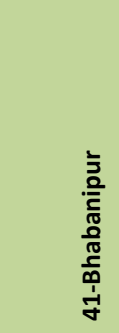 & 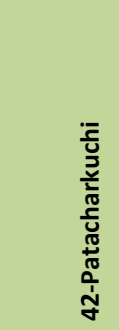 & 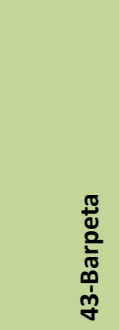 & $\begin{array}{l}\frac{\pi}{5} \\
\frac{\pi}{5} \\
\frac{J}{d}\end{array}$ & 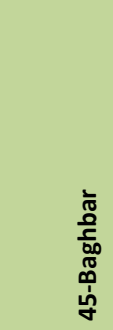 \\
\hline TOTAL VOTER & 205936 & 176306 & 162014 & 182297 & 207844 & 207571 & 223041 & 175037 & 159987 & 230013 & 148048 & 144190 & 208957 & 211920 & 165903 \\
\hline BJP & $x x x$ & $x x x$ & 45733 & $x x x$ & $x x x$ & 77275 & $x x x$ & $x x x$ & 14053 & 85872 & $x x x$ & 81284 & $x x x$ & 11408 & 3038 \\
\hline INC & $x x x$ & 44633 & $x X X$ & 93276 & 112954 & 78551 & 112995 & 85752 & 76026 & $x x x$ & $x x x$ & 18431 & 111083 & $x x x$ & 79357 \\
\hline AGP & $x x x$ & 82800 & $x X X$ & 60495 & 65869 & $x x x$ & 67747 & 39728 & 54046 & $x x x$ & 52748 & $x \mathrm{XX}$ & 66364 & $x X X$ & $x x x$ \\
\hline AIUDF & $x x x$ & $x x x$ & $x X X$ & $x x x$ & $x X X$ & $x x x$ & $x X X$ & $x x x$ & $x x x$ & $x X X$ & 55975 & $x x x$ & $x x x$ & 156183 & 65415 \\
\hline AJP & $x x x$ & 13988 & 9951 & 1264 & $x x x$ & $x x x$ & 1249 & 699 & 915 & $x x x$ & $x x x$ & 9831 & $X X X$ & 784 & $x X X$ \\
\hline BPF & 65767 & $x x x$ & 44730 & $x x x$ & $x X X$ & $x X x$ & $x X X$ & $x X x$ & $x X X$ & $x X x$ & $x X x$ & $x X x$ & $x X X$ & $x x x$ & $x X x$ \\
\hline UPPL & 97087 & $x x x$ & 35582 & $x x x$ & $x x x$ & $x x x$ & $x \mathrm{xx}$ & $x \mathrm{xx}$ & $x x x$ & $x x x$ & $x x x$ & $x x x$ & $x x x$ & $x x x$ & $x x x$ \\
\hline $\mathrm{CPI}(\mathrm{M})$ & $x x x$ & $x x x$ & $x x x$ & $x x x$ & $x x x$ & $x x x$ & $x x x$ & $x x x$ & $x x x$ & 96134 & $x x x$ & $x X X$ & $x x x$ & $x x x$ & $x x x$ \\
\hline NOTA & 2485 & 2179 & 1388 & 1025 & 1642 & 1367 & 1706 & 1308 & 970 & 1896 & 1037 & 1685 & 1727 & 890 & 740 \\
\hline OTHERS & 6490 & 10030 & 2531 & 3157 & 4594 & 23562 & 11777 & 30800 & 3793 & 7558 & 15843 & 2183 & 2818 & 16240 & 2726 \\
\hline RAIJOR DAL & $X X X$ & $\mathrm{XXX}$ & $\mathrm{XXX}$ & $\mathrm{XXX}$ & $\mathrm{XXX}$ & $\mathrm{XXX}$ & $\mathrm{XXX}$ & $\mathrm{XXX}$ & $\mathrm{XXX}$ & $\mathrm{XXX}$ & $\mathrm{XXX}$ & $\mathrm{XXX}$ & $\mathrm{XXX}$ & $\mathrm{XXX}$ & $\mathrm{XXX}$ \\
\hline REJECTED & 1002 & 331 & 664 & 321 & 143 & 75 & 175 & 9 & 22 & 390 & 220 & 426 & 422 & 80 & 122 \\
\hline TENDER & $x x x$ & 1 & $x x x$ & $x x x$ & $x x x$ & $x x x$ & $x x x$ & $x X x$ & $x x x$ & $x x x$ & $x X X$ & $x x x$ & $x x x$ & $x x x$ & $x x x$ \\
\hline TOTAL VOTE CAST & 172831 & 153962 & 140579 & 159538 & 185202 & 180830 & $x X X$ & 158296 & 309812 & 191850 & 125823 & 113840 & 182414 & 185585 & 151398 \\
\hline
\end{tabular}




\begin{tabular}{|c|c|c|c|c|c|c|c|c|c|c|c|c|c|c|c|}
\hline 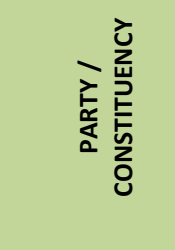 & 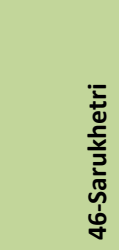 & 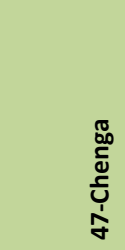 & 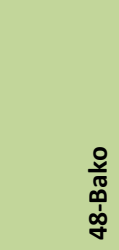 & 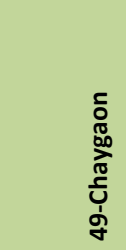 & 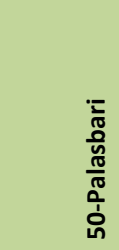 & 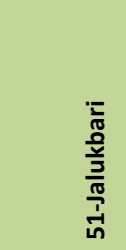 & 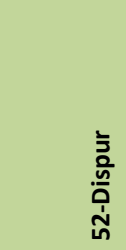 & 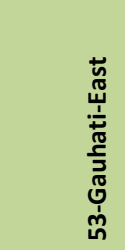 & 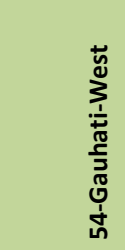 & 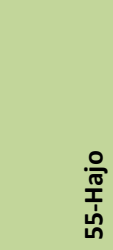 & 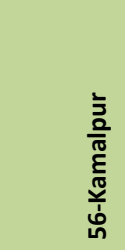 & 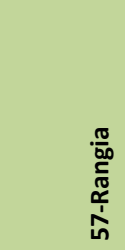 & 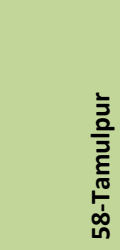 & 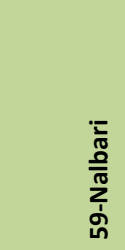 & 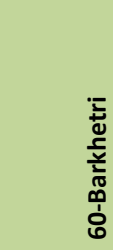 \\
\hline TOTAL VOTER & 206383 & 145283 & 236661 & 192597 & 158441 & 204691 & 412114 & 239586 & 297063 & 178082 & 180301 & 195439 & 215552 & 207754 & 196918 \\
\hline BJP & $x x x$ & $x x x$ & $x x x$ & $x x x$ & 68311 & 130762 & 196043 & 113461 & $x x x$ & 66165 & 81083 & 84844 & $x x x$ & 106190 & 81772 \\
\hline INC & 77045 & 22573 & 120613 & 93864 & 27320 & 28851 & 74386 & 29361 & 59084 & 28504 & 62969 & $x x x$ & $x X X$ & 56733 & 85826 \\
\hline AGP & 47504 & 23373 & 68147 & 65820 & $x X X$ & $x x x$ & $x X X$ & $x x x$ & 137533 & $x X X$ & $x x x$ & $x X X$ & $x x x$ & $x X X$ & $x X X$ \\
\hline AIUDF & 44805 & 75312 & $x x x$ & $x x x$ & $x x x$ & $x x x$ & $x X X$ & $x x x$ & $x X x$ & $x x x$ & $x X X$ & $x x x$ & $x X X$ & $X X X$ & 1106 \\
\hline AJP & 3097 & 733 & $x X X$ & 2481 & 28641 & $x x x$ & 15636 & 21049 & 5770 & 51797 & $x x x$ & 3560 & $x x x$ & 11778 & 2582 \\
\hline BPF & $x x x$ & $x x x$ & $X X X$ & $x x x$ & $X X X$ & $x x x$ & $X X X$ & $x x x$ & $x x x$ & $x x x$ & $x x x$ & $x x x$ & 46635 & $x x x$ & $x x x$ \\
\hline UPPL & $x x x$ & $x x x$ & $x X X$ & $x X X$ & $x x x$ & $x X X$ & $x x x$ & $x x x$ & $x x x$ & $x x x$ & $x x x$ & $x x x$ & 78818 & $x x x$ & $x x x$ \\
\hline $\mathrm{CPI}(\mathrm{M})$ & $x x x$ & $x X X$ & $x x x$ & $x x x$ & $x x x$ & $x X X$ & $x x x$ & $x X x$ & $x x x$ & $x X X$ & $x X x$ & 64624 & $x x x$ & $x X X$ & $x X X$ \\
\hline NOTA & 1265 & 696 & 3723 & 1487 & 1427 & 2157 & 5782 & 3417 & 3925 & 1100 & 1605 & 1925 & 2562 & 1808 & 941 \\
\hline OTHERS & 5168 & 5302 & 12571 & 2997 & 6147 & 7197 & 14471 & 3399 & 23402 & 4099 & 4679 & 7869 & 40564 & 2826 & 1292 \\
\hline RAIJOR DAL & $x x x$ & $x X X$ & $x X X$ & $x X X$ & $x X X$ & $x x x$ & $x X X$ & $x x x$ & $x X x$ & $x X X$ & $x x x$ & $x x x$ & $x x x$ & $x X X$ & $x X x$ \\
\hline REJECTED & 283 & 102 & 323 & 239 & 147 & 188 & 240 & $x x x$ & 96 & 134 & 172 & 327 & 139 & 575 & 3 \\
\hline TENDER & $x x x$ & $x x x$ & $x X X$ & $x x x$ & $x x x$ & 2 & $x x x$ & 5 & 2 & $x x x$ & $x x x$ & $x x x$ & $x x x$ & $x x x$ & $x x x$ \\
\hline $\begin{array}{l}\text { TOTAL VOTE } \\
\text { CAST }\end{array}$ & 179167 & 128091 & 205377 & 166888 & 131993 & 169157 & 306558 & 170692 & 229812 & 151799 & 150508 & 163149 & 168718 & 179910 & 173522 \\
\hline
\end{tabular}




\begin{tabular}{|c|c|c|c|c|c|c|c|c|c|c|c|c|c|c|c|}
\hline 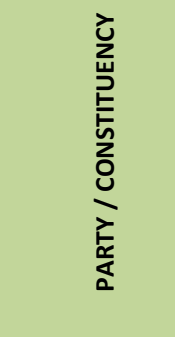 & 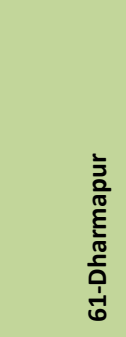 & 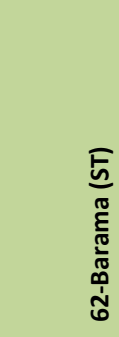 & 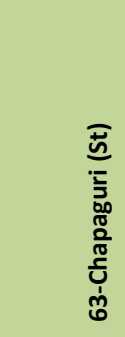 & 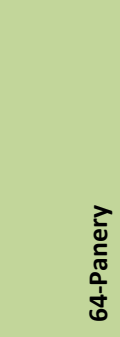 & 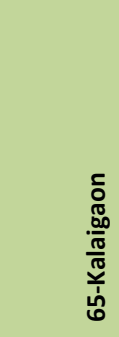 & 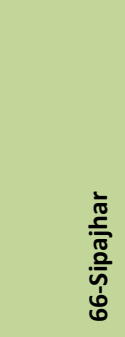 & 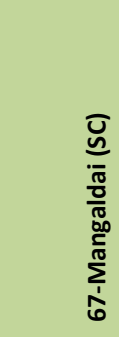 & 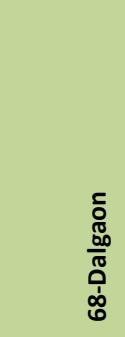 & 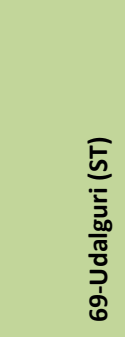 & $\begin{array}{l}\frac{1}{\pi} \\
\frac{0}{\pi} \\
\sum_{1}^{\pi} \\
0\end{array}$ & 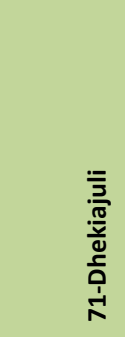 & 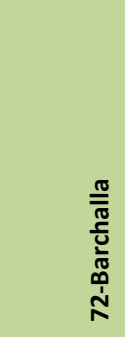 & & 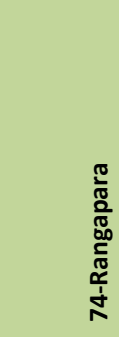 & 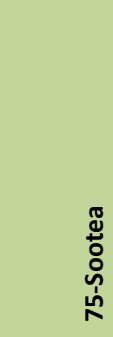 \\
\hline TOTAL VOTER & 141911 & 169810 & 161197 & 155257 & 184450 & 178319 & 237615 & 240796 & 158724 & 160449 & 217766 & 174036 & 147783 & 166718 & 190981 \\
\hline BJP & 68362 & $x x x$ & $x x x$ & 72639 & 53713 & 74739 & 87032 & $x x x$ & $x x x$ & 38352 & 93768 & 70569 & & 70172 & 84807 \\
\hline INC & 43328 & $x x x$ & $x x x$ & $x x x$ & $x x x$ & 67605 & 111386 & 62959 & $x x x$ & $x x x$ & 58698 & 52787 & 61331 & 47827 & 60432 \\
\hline AGP & $x x x$ & $x x x$ & $x x x$ & $x x x$ & $x x x$ & $x x x$ & $x x x$ & 28344 & $x x x$ & $x x x$ & $x x x$ & $x x x$ & 71454 & $x x x$ & $\mathrm{XXX}$ \\
\hline AIUDF & $x x x$ & $x x x$ & $x x x$ & $x x x$ & $x x x$ & $x x x$ & $x x x$ & 118342 & $x x x$ & $x x x$ & $x x x$ & $x x x$ & $x x x$ & $x x x$ & $x x x$ \\
\hline AJP & 6527 & $x x x$ & $x X X$ & $x x x$ & 2908 & 2201 & 2746 & $x x x$ & $x x x$ & $x x x$ & 1560 & 10192 & 8686 & 2976 & $x x x$ \\
\hline BPF & $x x x$ & 38613 & 35065 & 36787 & 60815 & $x x x$ & $x x x$ & $x x x$ & 56916 & 54409 & $x x x$ & $x x x$ & $x x x$ & $x x x$ & $x x x$ \\
\hline UPPL & $x x x$ & 62385 & 61804 & $x x x$ & 16871 & $x x x$ & $x x x$ & $x x x$ & 61767 & 28413 & $x x x$ & $x x x$ & $x x x$ & $x x x$ & $x x x$ \\
\hline $\mathrm{CPI}(\mathrm{M})$ & $x x x$ & $x x x$ & $x x x$ & $x x x$ & $x x x$ & $x x x$ & $x x x$ & $x x x$ & $x x x$ & $x x x$ & $x x x$ & $x x x$ & $x x x$ & $x x x$ & $x x x$ \\
\hline NOTA & 1088 & 2092 & 1884 & 2335 & 1324 & 1326 & 1567 & 1689 & 3805 & 1785 & 2559 & 1856 & 2050 & 2273 & 2411 \\
\hline OTHERS & 1190 & 30257 & 28470 & 6398 & 12487 & 2634 & 980 & 3038 & $x x x$ & 5597 & 8225 & 1624 & 6312 & 8661 & 2441 \\
\hline RAIJOR DAL & $x x x$ & $x x x$ & $x x x$ & $x x x$ & $x x x$ & $x X X$ & $x x x$ & $x x x$ & $x X X$ & $x x x$ & $x x x$ & $x x x$ & $x x x$ & $x x x$ & $x x x$ \\
\hline REJECTED & 13 & 16 & 526 & 335 & 189 & 110 & 282 & 93 & 107 & 454 & 470 & 34 & 552 & 21 & 433 \\
\hline TENDER & $x x x$ & $x x x$ & $x x x$ & $x x x$ & $x x x$ & $x x x$ & $x x x$ & $x x x$ & $x x x$ & $x x x$ & $x x x$ & $x x x$ & $x x x$ & $x x x$ & 1 \\
\hline $\begin{array}{l}\text { TOTAL VOTE } \\
\text { CAST }\end{array}$ & 120508 & 133363 & 127749 & 118494 & 148307 & 148615 & 203993 & 214465 & 122595 & 129010 & 165280 & 137062 & 150385 & 131930 & 150525 \\
\hline
\end{tabular}




\begin{tabular}{|c|c|c|c|c|c|c|c|c|c|c|c|c|c|c|c|}
\hline 总 & 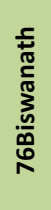 & $\begin{array}{l}\frac{\bar{\pi}}{\pi} \\
\frac{0}{0} \\
\stackrel{0}{1} \\
\hat{N}\end{array}$ & 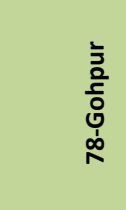 & 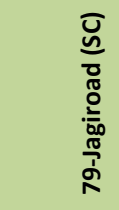 & 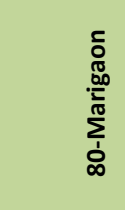 & 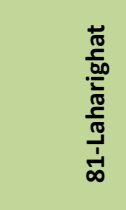 & $\begin{array}{l}\bar{J} \\
\frac{n}{\pi} \\
\frac{\pi}{\pi} \\
\stackrel{\pi}{1} \\
\infty\end{array}$ & 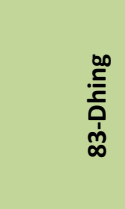 & 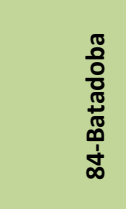 & 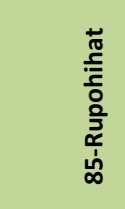 & 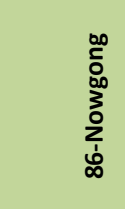 & 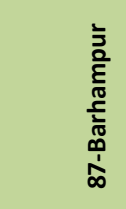 & 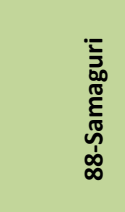 & 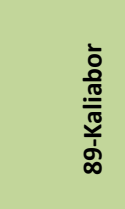 & 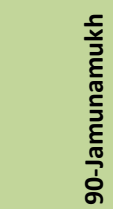 \\
\hline TOTAL VOTER & & & 204613 & 238898 & 193079 & 186704 & 221878 & 231325 & 166352 & 202820 & 189965 & 179641 & 165045 & 147083 & 221863 \\
\hline BJP & & & 93224 & 106643 & 81657 & 34732 & $x x x$ & 9048 & 51458 & 25739 & 81098 & 70111 & 55025 & $x x x$ & $x x x$ \\
\hline INC & & & 63930 & 77139 & $x x x$ & 60932 & 89511 & $x x x$ & 84278 & 132091 & 70015 & 69360 & 81123 & 44957 & $x x x$ \\
\hline AGP & & & $x x x$ & $x x x$ & $x x x$ & $x x x$ & 76453 & $x x x$ & $x x x$ & $x x x$ & $x x x$ & $x x x$ & $x x x$ & 73677 & 18342 \\
\hline AIUDF & & & $x x x$ & $x x x$ & $x x x$ & $x x x$ & $x x x$ & 145888 & $x x x$ & $x x x$ & $x x x$ & $x x x$ & $x x x$ & $x x x$ & 136902 \\
\hline AJP & & & 2904 & 12815 & 45125 & 1371 & 5616 & 1139 & $x x x$ & 10006 & 2009 & 1922 & 1678 & 2627 & 3292 \\
\hline BPF & & & $x x x$ & $x x x$ & $x x x$ & $x x x$ & $x x x$ & $x x x$ & $x x x$ & $x x x$ & $x x x$ & $x x x$ & $x x x$ & $x x x$ & $x x x$ \\
\hline UPPL & & & $x x x$ & $x x x$ & $\mathrm{xXX}$ & $x x x$ & $\mathrm{XXX}$ & $x x x$ & $x x x$ & $\mathrm{XXX}$ & $x x x$ & $\mathrm{xXX}$ & $\mathrm{XXX}$ & $\mathrm{xXX}$ & $x x x$ \\
\hline $\mathrm{CPI}(\mathrm{M})$ & & & $x x x$ & $x x x$ & 27290 & $x x x$ & $x x x$ & $x x x$ & $x x x$ & $x x x$ & $x x x$ & $x x x$ & $x x x$ & $x x x$ & $x x x$ \\
\hline NOTA & & & 1753 & 1595 & 1571 & 1073 & 1517 & 1820 & 1078 & 997 & 1095 & 1291 & 1116 & 1809 & 2575 \\
\hline OTHERS & & & 1352 & 903 & 939 & 65261 & 5752 & 49349 & 3612 & 12119 & 1725 & 1273 & 705 & 1676 & 27071 \\
\hline RAIJOR DAL & & & $x x x$ & $\mathrm{xxx}$ & $x x x$ & $x x x$ & $x x x$ & $x x x$ & $x x x$ & $x x x$ & $x x x$ & $x x x$ & $x x x$ & $x x x$ & $x x x$ \\
\hline REJECTED & & & $x x x$ & 589 & 496 & 1081 & 241 & 83 & 130 & 538 & 195 & 152 & 190 & 145 & 127 \\
\hline TENDER & & & $x x x$ & $x x x$ & $x x x$ & $x x x$ & $x x x$ & $x x x$ & $x x x$ & 1 & 1 & $x \mathrm{XX}$ & $x x x$ & $x x x$ & $x x x$ \\
\hline $\begin{array}{l}\text { TOTAL VOTE } \\
\text { CAST }\end{array}$ & & & 163163 & 199684 & 157078 & 164450 & 179090 & 207327 & 140556 & 181491 & 156138 & 144109 & 139837 & 124891 & 188309 \\
\hline
\end{tabular}




\begin{tabular}{|c|c|c|c|c|c|c|c|c|c|c|c|c|c|c|c|}
\hline 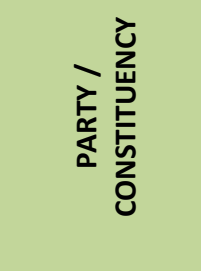 & 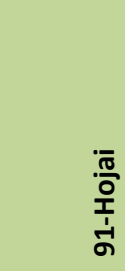 & 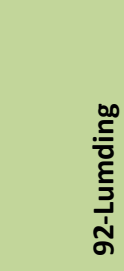 & 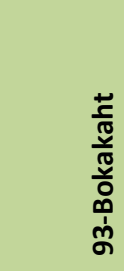 & 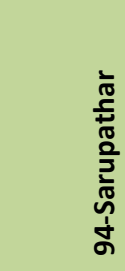 & 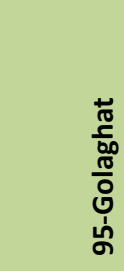 & 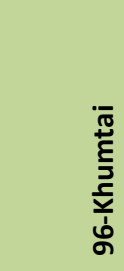 & 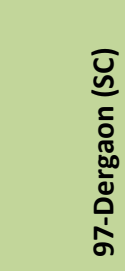 & 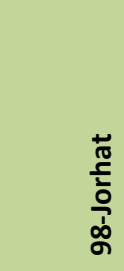 & $\begin{array}{l}E \\
\bar{n} \\
\overline{\bar{n}} \\
\sum_{\delta}^{\pi} \\
\delta\end{array}$ & 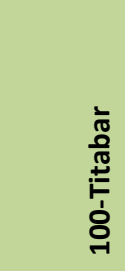 & 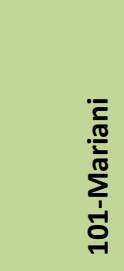 & 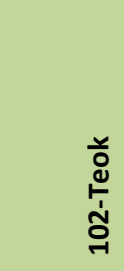 & 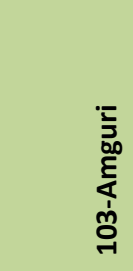 & 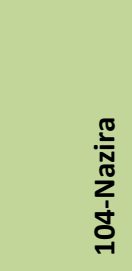 & 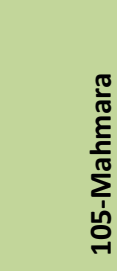 \\
\hline TOTAL VOTER & 266431 & 212304 & 147846 & 267594 & 205586 & 141259 & 174870 & 186273 & 132403 & 156559 & 123568 & 136828 & 124890 & 133974 & 138108 \\
\hline BJP & 125790 & 89108 & $x x x$ & 107090 & 81651 & 65655 & $x X X$ & 68321 & 71436 & 50924 & 44862 & & & 51704 & 51282 \\
\hline INC & 92008 & 77377 & $x x x$ & 67731 & 72326 & 38522 & 51546 & 61833 & 28244 & 64303 & 47308 & 46205 & 43712 & 52387 & 38147 \\
\hline AGP & $x x x$ & $x x x$ & 72930 & $x x x$ & $x x x$ & $x x x$ & 64043 & $x x x$ & $x x x$ & $x x x$ & $x x x$ & 47555 & 49891 & $x x x$ & $x x x$ \\
\hline AIUDF & $x x x$ & $x x x$ & $x x x$ & $x x x$ & $x x x$ & $x x x$ & $x x x$ & $x x x$ & $x x x$ & $x x x$ & $x x x$ & $x x x$ & $x x x$ & $x x x$ & $x x x$ \\
\hline AJP & $x x x$ & 3260 & 2334 & 27656 & 5062 & 7368 & 7585 & 6925 & 3246 & 3885 & $x x x$ & $x x x$ & 6987 & 2896 & 11357 \\
\hline BPF & $x x x$ & $x x x$ & $x x x$ & $x x x$ & $x x x$ & $x x x$ & $x x x$ & $x x x$ & $x x x$ & $x x x$ & $x x x$ & $x x x$ & $x x x$ & $x x x$ & $x x x$ \\
\hline UPPL & $x x x$ & $x x x$ & $x x x$ & $x x x$ & $x x x$ & $x x x$ & $x x x$ & $x x x$ & $x x x$ & $x x x$ & $x x x$ & $x x x$ & $x x x$ & $x x x$ & $x x x$ \\
\hline CPI(M) & $x x x$ & $x x x$ & $x x x$ & $x x x$ & $x x x$ & $x x x$ & $x x x$ & $x x x$ & $x X X$ & $x x x$ & $x x x$ & $x x x$ & $x X x$ & $x x x$ & $x x x$ \\
\hline NOTA & 1724 & 1485 & 2482 & 2945 & 2245 & 1399 & 2441 & 1717 & 1075 & 1562 & 2056 & 1927 & 1313 & 1470 & 1340 \\
\hline OTHERS & 2574 & 3349 & 42681 & 2564 & $x x x$ & 3289 & 7487 & 1100 & 1781 & 901 & 1612 & 8185 & 1981 & 1061 & 11371 \\
\hline RAIJOR DAL & $x x x$ & $x x x$ & $x x x$ & $x x x$ & $x x x$ & $x x x$ & $x x x$ & $x x x$ & $x x x$ & $x x x$ & $x x x$ & $x x x$ & $x x x$ & $x x x$ & $x x x$ \\
\hline REJECTED & 19 & 11 & 128 & 63 & 231 & 103 & 391 & 315 & 200 & 343 & 200 & 135 & 108 & 52 & 159 \\
\hline TENDER & $x x x$ & $x x x$ & $x x x$ & $x x x$ & $x x x$ & $x x x$ & $x x x$ & $x x x$ & $x x x$ & $x x x$ & $x x x$ & $x x x$ & $x x x$ & $x x x$ & $x x x$ \\
\hline $\begin{array}{c}\text { TOTAL VOTE } \\
\text { CAST }\end{array}$ & 222115 & 174590 & 120555 & 208049 & 161515 & 116336 & 133493 & 140211 & 105982 & 121918 & 96038 & 104007 & 103992 & 109570 & 113656 \\
\hline
\end{tabular}




\begin{tabular}{|c|c|c|c|c|c|c|c|c|c|c|c|c|c|c|c|}
\hline 总 & 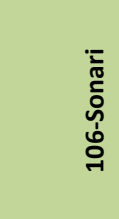 & 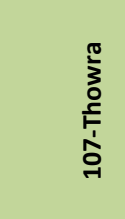 & 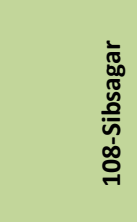 & 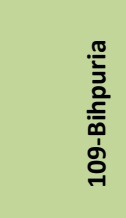 & $\begin{array}{l}\pi \\
\frac{0}{5} \\
\frac{0}{0} \\
0 \\
0 \\
2 \\
2 \\
0 \\
\frac{\pi}{7}\end{array}$ & 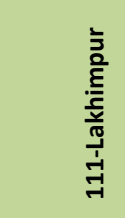 & 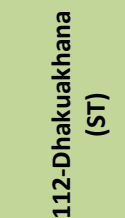 & 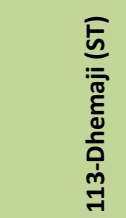 & 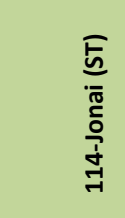 & 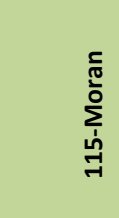 & 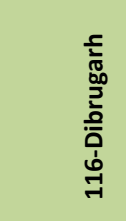 & 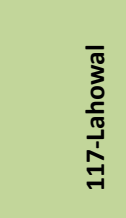 & 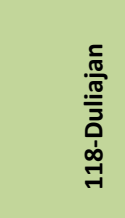 & 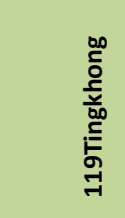 & 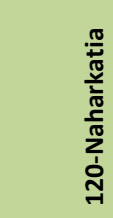 \\
\hline TOTAL VOTER & 178790 & 115364 & 151675 & 152309 & 226744 & 189672 & 210546 & 247222 & 312180 & 143170 & 150348 & 154651 & 166137 & 149731 & 142035 \\
\hline BJP & 69690 & 46020 & 45344 & 58979 & $x x x$ & 70387 & 86382 & 87681 & 168411 & 55604 & 68762 & 59295 & 54762 & 62675 & 47268 \\
\hline INC & 54573 & 48026 & 19329 & 48801 & 52905 & 67351 & 76786 & 44832 & 57424 & 33263 & 30757 & 42047 & 46652 & 34281 & 32292 \\
\hline AGP & $x x x$ & $x x x$ & $x x x$ & $x x x$ & 35279 & 12486 & $x x x$ & $x x x$ & $x x x$ & $x x x$ & $x x x$ & $x x x$ & $x x x$ & $x x x$ & 4094 \\
\hline AIUDF & $x x x$ & $x x x$ & $x x x$ & $x x x$ & $x x x$ & $x x x$ & $x x x$ & $x x x$ & $x x x$ & $x x x$ & $x x x$ & $x x x$ & $x x x$ & $x x x$ & $x x x$ \\
\hline AJP & 16799 & 1705 & $x x x$ & 6510 & 1934 & 2453 & 2988 & 56889 & 7726 & 9499 & 11062 & 10726 & 24192 & 16690 & 25231 \\
\hline BPF & $x x x$ & $x x x$ & $x x x$ & $x x x$ & $x x x$ & $x x x$ & $x x x$ & $x x x$ & $x x x$ & $x x x$ & $x x x$ & $x x x$ & $x x x$ & $x x x$ & $x x x$ \\
\hline UPPL & $x x x$ & $x x x$ & $x x x$ & $x x x$ & $x x x$ & $x x x$ & $x x x$ & $x x x$ & $x x x$ & $x x x$ & $x x x$ & $x x x$ & $x x x$ & $x x x$ & $\mathrm{xXX}$ \\
\hline CPI(M) & $x x x$ & $x x x$ & $x x x$ & $x x x$ & $x x x$ & $x x x$ & $x x x$ & $x x x$ & $x x x$ & $x x x$ & $x x x$ & $x x x$ & $x x x$ & $x x x$ & $x x x$ \\
\hline NOTA & 2510 & 1146 & 639 & 814 & 2102 & 1114 & 1254 & 1643 & 2676 & 1910 & 1845 & 2954 & 2193 & 1928 & 1454 \\
\hline OTHERS & 1617 & $x x x$ & 1688 & 6411 & 101281 & 2507 & 2534 & 2367 & 8921 & 11645 & 1356 & 8164 & 1518 & 3445 & 696 \\
\hline RAIJOR DAL & $x x x$ & $x x x$ & 57219 & $x x x$ & $x x x$ & $x x x$ & $x x x$ & $x x x$ & $x x x$ & $x x x$ & $x x x$ & $x x x$ & $x x x$ & $x x x$ & $x x x$ \\
\hline REJECTED & 106 & 319 & 298 & 187 & $x x x$ & 88 & 320 & $x x x$ & 553 & 343 & 149 & 110 & 206 & 200 & 223 \\
\hline TENDER & $x x x$ & $x x x$ & $x x x$ & $x x x$ & $x x x$ & $x x x$ & $x x x$ & $x x x$ & $x x x$ & $x x x$ & 1 & 1 & $x x x$ & $x x x$ & $x x x$ \\
\hline $\begin{array}{l}\text { TOTAL VOTE } \\
\text { CAST }\end{array}$ & 145295 & 97216 & 124517 & 121702 & 193501 & 156386 & 170264 & 193412 & 245711 & 112264 & 113932 & 123297 & 129523 & 119219 & 111258 \\
\hline
\end{tabular}




\begin{tabular}{|c|c|c|c|c|c|c|c|}
\hline 飠 & 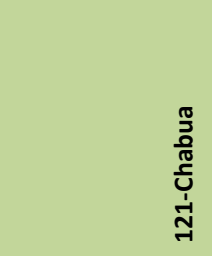 & 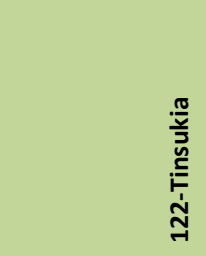 & 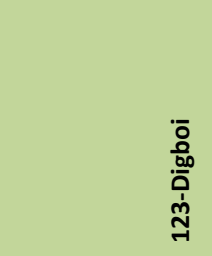 & 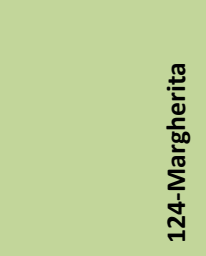 & 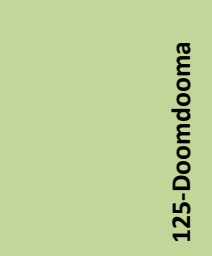 & 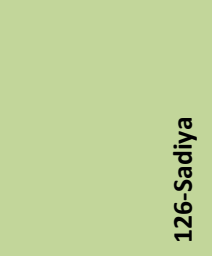 & \\
\hline TOTAL VOTER & 165934 & 173562 & 140259 & 195861 & 152470 & 189382 & 22532731 \\
\hline BJP & $x X X$ & 85857 & 59217 & 86640 & 49119 & 64855 & 6018558 \\
\hline INC & 34824 & $x x x$ & 32241 & 28140 & 40981 & 42771 & 5505536 \\
\hline AGP & 53554 & $x x x$ & $x x x$ & $x x x$ & $x x x$ & $x x x$ & 1573823 \\
\hline AIUDF & $x x x$ & $x x x$ & $x x x$ & $x x x$ & $x x x$ & $x x x$ & 1732505 \\
\hline AJP & $X X X$ & 15060 & 13001 & 22935 & 4348 & 29849 & 696356 \\
\hline BPF & $x X X$ & $x x x$ & $x x x$ & $x X X$ & $x x x$ & $x X X$ & 651073 \\
\hline UPPL & $x x x$ & $x x x$ & $x x x$ & $x x x$ & $x x x$ & $x x x$ & 651744 \\
\hline CPI(M) & $x X X$ & $x X X$ & $x x x$ & $x X X$ & $x x x$ & $x X X$ & 188048 \\
\hline NOTA & 3332 & 2539 & 2733 & 2536 & 3186 & 1918 & 211827 \\
\hline OTHERS & 37643 & 27469 & $x x x$ & 13028 & 20125 & 3182 & 1274344 \\
\hline RAIJOR DAL & $x x x$ & $x x x$ & $x x x$ & $x X X$ & $x x x$ & $x x x$ & 57219 \\
\hline REJECTED & 138 & 114 & 85 & 27 & 148 & 311 & 26884 \\
\hline TENDER & 6 & $x x x$ & 4 & 11 & 3 & $x X X$ & 43 \\
\hline TOTAL VOTE CAST & 129497 & 131039 & 107281 & 153317 & 117910 & 142886 & 18552298 \\
\hline
\end{tabular}

